\title{
Corrigendum: Acidification of East Siberian Arctic Shelf waters through addition of freshwater and terrestrial carbon
}

Igor Semiletov, Irina Pipko, Örjan Gustafsson, Leif G. Anderson, Valentin Sergienko, Svetlana Pugach, Oleg Dudarev, Alexander Charkin, Alexander Gukov, Lisa Bröder, August Andersson, Eduard Spivak and Natalia Shakhova

Nature Geoscience 9, 361-365 (2016); published online 18 April 2016; corrected after print 6 May 2016.

In the version of the Letter originally published, in the first sentence of the Fig. 4 caption, ' $\delta{ }^{18} \mathrm{C}$ ' should have been ' $\delta{ }^{18} \mathrm{O}$ '. This has been corrected in the online versions of the Letter. 